\title{
Phenolic compounds of Hibiscus sabdariffa and influence of organic residues on its antioxidant and antitumoral properties
}

\author{
Formagio, ASN. ${ }^{a *}$, Ramos, DD. ${ }^{a}$, Vieira, MC. ${ }^{a}$, Ramalho, SR. ${ }^{b}$, Silva, MM. ${ }^{b}$, \\ Zárate, NAH. ${ }^{a}$ Foglio, MA. ${ }^{c}$ and Carvalho, JE. ${ }^{c}$ \\ aFacudade de Ciências Agrárias, Universidade Federal da Grande Dourados - UFGD, Rua João Rosa Góes, 1761, \\ Progresso, CEP 79825-070, Dourados, MS, Brazil

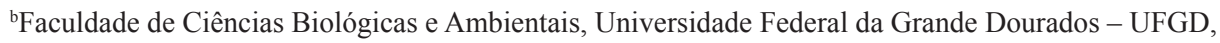 \\ Rua João Rosa Góes, 1761, Vila Progresso, CEP 79825-070, Dourados, MS, Brazil \\ ${ }^{\circ}$ Centro Pluridisciplinar de Pesquisas Químicas, Biológicas e Agrícolas, Universidade Estadual de Campinas - Unicamp, \\ Cidade Universitária Zeferino Vaz, Barão Geraldo, CEP 13083-970, Campinas, SP, Brazil \\ *e-mail: aneliseformagio@ufgd.edu.br
}

Received: May 10, 2013 - Accepted: September 3, 2013 - Distributed: March 31, 2015

(With 1 figure)

\begin{abstract}
The aim of this study was to evaluate the phenolic and flavonoids contents and the antioxidant and antitumoral activity of leaf and calyx methanolic extracts from Hibiscus sabdariffa (roselle) cultivated with poultry litter and organosuper ${ }^{\circledR}$ under three modes of application. The total phenolic content in the each extract was determined using the Folin-Ciocalteu reagent and for aluminium chloride flavonoids. The antioxidant parameters were analyzed using a 2, 2-diphenyl-1picrylhydrazyl (DPPH) free radical scavenging assay. An antitumor colorimetric assay using sulforhodamine $\mathrm{B}$. The highest contents of phenolic and flavonoids were observed in leaf extracts (389.98 and $104.52 \mathrm{mg} \mathrm{g}^{-1}$, respectively) and calyx extracts ( 474.09 and $148.35 \mathrm{mg} \mathrm{g}^{-1}$, respectively) from plants cultivated with organosuper ${ }^{\circledR}$, although these values did not differ significantly from those observed for the other treatments. The average $\mathrm{IC}_{50}$ of leaves $\left(43.48 \mu \mathrm{g} \mathrm{mL} \mathrm{m}^{-1}\right)$ and calyces $\left(37.15 \mu \mathrm{g} \mathrm{mL}^{-1}\right)$ demonstrated that both have substances that may contribute to free radical scavenging action. The methanol extract from calyces showed significant selective activity against a leukemia line (K-562), with $\mathrm{IC}_{50}$ values of $0.12 \mathrm{mg} \mathrm{mL}^{-1}$ (organosuper ${ }^{\circledR}$ ) and $1.16 \mathrm{mg} \mathrm{mL}^{-1}$ (poultry litter), with concentration-dependent, cytotoxic and cytocidal effects.
\end{abstract}

Keywords: roselle, poultry litter, organosuper ${ }^{\circledR}$, phenolic, flavonoids, activity.

\section{Compostos fenólicos de Hibiscus sabdariffa e influência de resíduos orgânicos em sua propriedade antitumoral e antioxidante}

\begin{abstract}
Resumo
O objetivo deste estudo foi avaliar a atividade antioxidante, antitumoral e o conteúdo de fenólicos e flavonoides do extrato metanólico das folhas e cálices de Hibiscus sabdariffa (rosela) cultivada com cama de frango e organosuper ${ }^{\circledR}$ em três modos de aplicação. O conteúdo fenólico total de cada extrato foi determinado utilizando o reagente de Folin-Ciocalteu e cloreto de alumínio para flavonoides. Os parâmetros antioxidantes foram avaliados pelo ensaio de seqüestro de radical livre 2, 2-difenil-1-picrilhidrazil (DPPH). Na avaliação antitumoral utilizou-se o ensaio colorimétrico com sulforrodamina B. Observou-se o maior conteúdo de fenólicos e flavonoides em extratos de folhas (389.98 e $104.52 \mathrm{mg} \mathrm{g}^{-1}$, respectivamente) e extratos de cálice (474.09 e $148.35 \mathrm{mg} \mathrm{g}^{-1}$, respectivamente) de plantas cultivadas com organosupe ${ }^{\circledR}$, embora esses valores não diferiram significativamente daqueles observados para os outros tratamentos. O IC $\mathrm{IC}_{50}$ de folhas $\left(43.48 \mu \mathrm{g} \mathrm{mL}^{-1}\right)$ e cálices $\left(37.15 \mu \mathrm{g} \mathrm{mL} \mathrm{L}^{-1}\right)$ demonstrou que ambos têm substâncias que podem contribuir para a ação seqüestradora de radicais livres. $\mathrm{O}$ extrato metanólico dos cálices mostrou seletividade na linhagem de leucemia (K-562), com valores de $\mathrm{IC}_{50}$ de $0,12 \mathrm{mg} \mathrm{mL}^{-1}$ (organosuper ${ }^{\circledR}$ ) e $1,16 \mathrm{mg} \mathrm{mL}^{-1}$ (cama-defrango) com concentração-dependente e efeito citotóxico e citocida.
\end{abstract}

Palavras-chave: rosela, cama-de-frango, organosuper $^{\circledR}$, fenólicos, flavonoides, atividade. 


\section{Introduction}

Hibiscus sabdariffa L., (Malvaceae), commonly known as "roselle", is an important medicinal plant native to India and Malaysia, although it grows widely in the tropics and subtropics of both hemispheres and has become naturalized in many areas in Central America (Morton, 1987). The plant is an annual, erect, herbaceous sub-shrub with a deep root system. The plant has fibrous stems, small branches, as well as bright red and acidic-tasting calyces.

In folk medicine, an infusion from the calyces is used as a diuretic and to treat gastrointestinal disorders, liver diseases, fever, hypercholesterolemia, and hypertension (Monroy-Ortiz and Castillo-Espana, 2007). Extracts from the calyces are reported to have a variety of therapeutic effects in vivo and in vitro, including anticancer (OlveraGarcia et al., 2008; Lin et al., 2005) and antioxidant (Farombi and Fakoya, 2005; Ramakrishna et al., 2008) properties.

Calyces of $H$. sabdariffa have been the subject of a number of investigations and are known to contain polyphenolic acids, flavonoids and anthocyanins, such as delphinidin-3-O-glucoside, delphinidin-3-O-sambubioside, and cyanidin-3-O-sambubioside (Ali et al., 2005). In previous studies, Hibiscus anthocyanins and protocatechuic acid were shown to have strong antioxidant (Tseng et al., 1997; Wang et al., 2000; Lee et al., 2002) and anticancer effects in human leukemia and gastric carcinoma cells (Lin et al., 2005; Tseng et al., 1998, 2000; Chang et al., 2005).

Many studies also demonstrated an additional cardioprotective effect of anthocyanins, flavonoids and polyphenols, either through antioxidant-related mechanisms or by other means. H. sabdariffa extracts inhibited lowdensity lipoprotein (LDL) oxidation in vitro and decreased serum cholesterol levels in cholesterol-fed rats and rabbits (Chen et al., 2003, 2004).

Antioxidants are considered to be effective inhibitors of carcinogenesis as well as other conditions that are pathogenically associated with oxidative mechanisms. Many studies have supported the hypothesis that antioxidant nutrients and/or medicines play a protective role in human health (Ames et al., 1993). Therefore, as calyces are consumed throughout the world with culinary and medicinal objectives, and as calyces show potential for therapeutic use, it is necessary to investigate the potential production of $H$. sabdariffa and evaluate its constituents.

The amount of bioactive components in plants is influenced by agricultural management in which they are grown (fertilization, cultivation practices, etc.), and the efficacy of these phytochemicals depends on the concentration in the plants. Thus, the incorporation of organic fertilization is a logical step towards increasing production of medicinal plants. Furthermore, poultry litter represents a rich feedstock of carbon, nitrogen, phosphorous, potassium, and other nutrients (Mullins and Bendfeldt, 2001). However, studies with different extracts of $H$. sabdariffa poultry litter and different spacing cultivated were evaluated in antioxidant activity and content of phenols and flavonoids. The spacing did not influence on content of constituents, but the addition of poultry litter has enhanced the responses both in aqueous and ethanolic extract. The ethanolic extract has higher antioxidant activity (Ramos et al., 2011). The data indicate the importance of the continuity of phytochemical and cultivation studies and especially in the evaluation of other biological activities.

Thus, the aim of this study was to evaluate the phenolic and flavonoid contents, as well as the antioxidant and anticancer activities, of leaf and calyx extracts from H. sabdariffa that were cultivated with poultry litter and organosuper ${ }^{\circledR}$ under three modes of application.

\section{Material and Methods}

\subsection{Plant material and field phase}

H. sabdariffa plants were grown at the Medicinal Plant Nursery (HPM), of Federal University of Grande Dourados (UFGD), in Dourados, MS, between the months of December and July of 2009/2010. A voucher specimen (DDMS4593) was deposited at the Herbarium of the Federal University of Grande Dourados, Dourados, MS, Brazil. This area is located in the southern part of Mato Grosso do Sul, at an average altitude of $452 \mathrm{~m}\left(22^{\circ} 14^{\prime} 16^{\prime \prime}\right.$ $\left.\mathrm{S}, 54^{\circ} 49^{\prime} 2^{\prime \prime} \mathrm{W}\right)$. The climate is Cwa, by the Köppen classification system. The soil, originally from Cerrado vegetation, is classified as distroferric red latosol, with a sandy texture and a flat topography.

The treatments were composed of combinations of two organic waste sources, poultry litter $\left(10 \mathrm{tha}^{-1}\right)$ and $\operatorname{organosuper}^{\circledR}\left(10 \mathrm{t} \mathrm{ha}^{-1}\right)$, and three application modes (coverage, incorporated and coverage + incorporated) plus a control. The treatments were arranged in a $2 \times 4$ factorial, randomized block design with four replicates. The coverage + incorporated mode was applied at $5 \mathrm{t} \mathrm{ha}^{-1}+5 \mathrm{t} \mathrm{ha}^{-1}$. Leaves were harvested when the plants began flowering at 95 days after transplant (DAT). Two harvests of calyces were made from the remaining plants from each plot at 139 and 185 DAT, using the size of calyces (larger than $3.5 \mathrm{~cm})$ as an indication of the harvest point.

\subsection{Preparation of methanol extracts}

Leaves and calyces from $H$. sabdariffa cultivated with two organic waste sources, poultry litter $\left(10 \mathrm{tha}^{-1}\right)$ and organosuper ${ }^{\circledR}\left(10 \mathrm{tha}^{-1}\right)$, and three application modes (coverage, incorporated and coverage + incorporated), separately were dried in an oven (AC-035/81) of circulating air at $45^{\circ} \mathrm{C}$ for four days and subsequently crushed in a grinder of knives (MA340/A). The material obtained (50 g) was subjected to maceration for a period of $24 \mathrm{~h}$ in $300 \mathrm{~mL}$ of methanol (Dynamics ${ }^{\circledR}$ ) at room temperature, followed by filtration by filter paper. The process was repeated five times and the filtrates were pooled and concentrated under reduced pressure by rotary evaporator (MA-120) and lyophilized.

\subsection{Determination of total phenolic content}

Total phenolic compounds in the methanolic extract from leaves and calyces of $H$. sabdariffa were determined using the Folin-Ciocalteu method (Meda et al., 2005). 
Specifically, to each $100 \mu \mathrm{L}$ of extract in methanol $\left(1 \mathrm{~g} \mathrm{~L}^{-1}\right)$ was added $1.0 \mathrm{~mL}$ of distilled water and $0.5 \mathrm{~mL}$ of FolinCiocalteu's $(1: 10 \mathrm{v} / \mathrm{v})$ reagent. After $3 \mathrm{~min}$, a $1.5 \mathrm{~mL}$ saturated solution of $\mathrm{Na}_{2} \mathrm{CO}_{3}(2 \%)$ was added. After $30 \mathrm{~min}$ the optical density was measured by the absorbance at $765 \mathrm{~nm}$ using a spectrophotometer. The quantification was performed on the basis of a standard curve of gallic acid prepared in $80 \%$ methanol, and the results were expressed in milligrams of gallic acid equivalent per gram of extract. A methanol solution was used as a blank. The assays were performed in triplicate.

\subsection{Determination of total flavonoid content}

To determine the level of flavonoids, each $500 \mu \mathrm{L}$ of sample was combined with $1.50 \mathrm{~mL}$ of $95 \%$ ethanol, $0.10 \mathrm{~mL}$ of $10 \%$ aluminum chloride $\left(\mathrm{AlCl}_{3} \cdot 6 \mathrm{H}_{2} \mathrm{O}\right), 0.10 \mathrm{~mL}$ of sodium acetate $\left(\mathrm{NaC}_{2} \mathrm{H}_{3} \mathrm{O}_{2} \cdot 3 \mathrm{H}_{2} \mathrm{O}\right)\left(1 \mathrm{~mol} \mathrm{~L}^{-1}\right)$ and $2.80 \mathrm{~mL}$ of distilled water. The tubes were kept at room temperature for $40 \mathrm{~min}$. The optical density was measured by absorbance at $415 \mathrm{~nm}$ using a spectrophotometer. The same procedure was used in the analysis of a blank (Lin and Tang, 2007). To calculate the concentration of flavonoids, a calibration curve was prepared $(2.5,5.0,10.0$, $20.0,25.0,50.0,100.0$ and $125.0 \mu \mathrm{g}$ ) using quercetin as a standard. A linear regression was calculated from these data, and a line equation was obtained for subsequent use in the quantification of actual samples. The results were expressed in milligrams of quercetin equivalents per gram of extract. The assays were performed in triplicate.

\subsection{Qualitative analysis of antioxidant activity}

The extracts were analyzed by TLC using quercetin as a positive comparison. The plates were eluted in chloroform/ methanol $10 \%$ and, after drying, were nebulized with a solution of $0.4 \mathrm{mmol} \mathrm{L}^{-1} \mathrm{DPPH}$ in methanol. The cells were observed until the appearance of yellow spots on a background of purple coloration, indicating possible antioxidant activity (Soler-Rivas et al., 2000).

\subsection{DPPH free radical scavenging assay}

Free radical scavenging activity of the methanolic extract was determined using a 1,1-diphenyl-1-picrylhydrazyl (DPPH) free radical method (Blois, 1958). Various concentrations of the samples were added to $2 \mathrm{~mL}$ of daily prepared methanol solutions of DPPH $(0.1 \mathrm{mM})$. The mixture was shaken and left to stand at room temperature in the dark. After $30 \mathrm{~min}$, absorbance was measured at $517 \mathrm{~nm}$ against a blank containing all of the reagents except the test samples. Butylated hydroxytoluene (BHT) was used as the standard. The assays were performed in triplicate.

\subsection{The evaluation of anticancer activity}

The evaluation of anticancer activity of methanol extracts of leaves and calyces grown with organic waste (poultry litter and organosuper ${ }^{\circledR}$ ) was performed by a colorimetric method employing sulforhodamine B (Skehan et al., 1990), with doxorubicin as a positive control. One hundred microliters of a cell suspension were added to RPMI-1640/SFB ( $10 \%$ gentamicin, $50 \mu \mathrm{g} \mathrm{mL}^{-1}$ ) medium, in 96-well plates and incubated for $24 \mathrm{~h}$ at $37^{\circ} \mathrm{C}$ in $5 \% \mathrm{CO}_{2}$. After this period, a control plate was fixed by adding trichloroacetic acid to determine the number of cells at the time of drug addiction. The extracts were tested at concentrations of $0.25,2.5,25$ and $250 \mu \mathrm{g} \mathrm{mL}^{-1}$ and incubated for $48 \mathrm{~h}$. The plates were then stained by adding $50 \mu \mathrm{L}$ of the protein dye sulforhodamine B (SRB) $0.4 \%(\mathrm{w} / \mathrm{v})$, dissolved in $1 \%$ acetic acid, and incubated at $4{ }^{\circ} \mathrm{C}$ for $30 \mathrm{~min}$. The dye was resuspended in a solution of Trizma base $(10 \mu \mathrm{M}, \mathrm{pH} 10.5)$, and the absorbance at $540 \mathrm{~nm}$ was measured on a microplate reader.

\section{Statistical Analysis}

Statistical data were analyzed using variance analysis (ANOVA) followed by the Tukey test (HSD, honestly significant differences), with the level of significance set at $(\mathrm{p}<0.05)$ (Ribeiro Júnior and De Melo, 2008).

\section{Results}

The results for the determination of total phenols by Folin-Ciocalteu method, expressed as gallic acid equivalents per $g$ of methanol extract of leaves and calyces of $H$. sabdariffa grown under different organic waste and application conditions are presented in Table 1. The methanolic extract from leaves and calyces of $H$. sabdariffa

Table 1. Phenols and flavonoids from methanol extract of $H$. sabdariffa leaves and calyces cultivated with two organic wastes and three modes of application and a control ${ }^{\mathrm{a}}$.

\begin{tabular}{|c|c|c|c|c|c|}
\hline \multirow{2}{*}{$\begin{array}{c}\text { Organic } \\
\text { waste }\end{array}$} & \multirow{2}{*}{$\begin{array}{l}\text { Application } \\
\text { mode }\end{array}$} & \multicolumn{2}{|c|}{ Leaves } & \multicolumn{2}{|c|}{ Calyces } \\
\hline & & Phenol $^{\text {b }}$ & Flavonoids $^{\mathrm{c}}$ & Phenol $^{\text {b }}$ & Flavonoids $^{\mathrm{c}}$ \\
\hline Control & & $377.78 \pm 6.61 \mathrm{a}$ & $140.29 \pm 3.14 \mathrm{a}$ & $453.43 \pm 3.78 \mathrm{a}$ & $97.43 \pm 2.51 \mathrm{a}$ \\
\hline \multirow[t]{3}{*}{ Poultry litter } & Incorporated & $387.55 \pm 2.69 \mathrm{a}$ & $147.52 \pm 1.21 \mathrm{a}$ & $471.35 \pm 3.03 \mathrm{a}$ & $103.33 \pm 5.61 \mathrm{a}$ \\
\hline & Coverage & $380.68 \pm 3.30 \mathrm{a}$ & $141.77 \pm 5.98 \mathrm{a}$ & $454.66 \pm 9.08 \mathrm{a}$ & $95.85 \pm 1.85 \mathrm{a}$ \\
\hline & Inc. + Cov. & $377.50 \pm 2.82 \mathrm{a}$ & $142.72 \pm 3.63 \mathrm{a}$ & $468.45 \pm 7.66 \mathrm{a}$ & $96.65 \pm 0.79 \mathrm{a}$ \\
\hline \multirow[t]{3}{*}{ Organosuper $^{\circledR}$} & Incorporated & $389.98 \pm 5.98 \mathrm{a}$ & $148.35 \pm 2.42 \mathrm{a}$ & $474.09 \pm 4.39 \mathrm{a}$ & $104.52 \pm 4.85 \mathrm{a}$ \\
\hline & Coverage & $380.83 \pm 5.27 \mathrm{a}$ & $143.06 \pm 2.44 \mathrm{a}$ & $455.89 \pm 9.48 \mathrm{a}$ & $97.73 \pm 0.92 \mathrm{a}$ \\
\hline & Inc. + Cov. & $379.95 \pm 2.90 \mathrm{a}$ & $142.63 \pm 2.75 \mathrm{a}$ & $465.48 \pm 8.58 \mathrm{a}$ & $98.82 \pm 3.43 \mathrm{a}$ \\
\hline Means & & $382.04 \pm 4.22$ & $143.76 \pm 3.08$ & $463.34 \pm 6.57$ & $98.32 \pm 2.35$ \\
\hline
\end{tabular}

${ }^{a}$ Values represent means of triplicate determination $\pm \mathrm{SD}$; ${ }^{\mathrm{b}, \mathrm{c}}$ The results are expressed as (mg gallic acid equivalent/g extract and $\mathrm{mg}$ quercetin equivalent/g extract, respectively). Means followed by same letter in column do not differ based on the Tukey test $(\mathrm{p}<0.05)$. 
cultivated with incorporated organosuper ${ }^{\circledR}$ showed the highest phenol contents $\left(389.98 \mathrm{mg} \mathrm{g}^{-1}\right.$ and $474.09 \mathrm{mg}$ $\mathrm{g}^{-1}$, respectively); however, no significant difference was observed between treatments.

The highest flavonoid contents were also observed in leaf extract (104.52 $\left.\mathrm{mg} \mathrm{g}^{-1}\right)$ and calyces $\left(148.35 \mathrm{mg} \mathrm{g}^{-1}\right)$ in plants grown with incorporated organosuper ${ }^{\circledR}$, and these values did not differ from the other treatments (Table 1).

Preliminary qualitative evaluation of methanol extracts of leaves and calyces from different treatments (by TLC) suggested the existence of substances with antioxidant activity, as indicated by the chromatographic spots of yellow on purple background that resulted from the reduction of DPPH radical. The test data against the free radical are presented in Table 2 . The average $\mathrm{IC}_{50}$ values for leaves $\left(43.48 \mu \mathrm{g} \mathrm{mL}^{-1}\right)$ and calyces $\left(37.15 \mu \mathrm{g} \mathrm{mL}^{-1}\right)$ (Table 2) demonstrate that both have substances that may contribute to free radical scavenging action compared to the positive control BHT $\left(16.7 \mu \mathrm{g} \mathrm{mL}^{-1}\right)$.

Figure 1 shows the concentration-response curves of the control condition and for the methanol extract from the leaves and calyces of plants cultivated with incorporated poultry litter and organosuper ${ }^{\circledR}$ for the tested cell lines.
These curves compare the percentage of cell growth and the concentration of the sample used. The curves A and B show that the methanol extracts of leaves exhibited low activity against the leukemia cells, with $\mathrm{IC}_{50}$ values of $43.20 \mathrm{mg} \mathrm{mL}^{-1}$, when compared with the calyces (Table 3 ). The curves D and E show that the methanol extract of calyces showed significant selective activity for leukemia cells (K-562), with $\mathrm{IC}_{50}$ values of $0.12 \mathrm{mg}$ $\mathrm{mL}^{-1}$ and $1.16 \mathrm{mg} \mathrm{mL}^{-1}$, respectively. This effect was concentration dependent, and the extracts had cytotoxic and cytocidal effects. However, when the curves $\mathrm{C}$ and $\mathrm{F}$ were evaluated, no difference was observed in the activity of extracts from the leaves and calyces compared to the control (Table 3).

\section{Discussion}

Generally, the highest concentrations of phenols and flavonoids were observed in the calyces, with values ranging from 454.66 to $474.09 \mathrm{mg} \mathrm{g}^{-1}$ and 140.29 to $148.35 \mathrm{mg} \mathrm{g}^{-1}$, respectively, regardless of the form of plant cultivation. According to Juliani et al. (2009), the total content of anthocyanins (by HPLC) in calyces of H. sabdariffa varies

Table 2. Antioxidant activity of methanol extract from leaves and calyces of $H$. sabdariffa cultivated with two organic wastes and three modes of application plus a controla

\begin{tabular}{|c|c|c|c|}
\hline \multirow{2}{*}{ Organic waste } & \multirow{2}{*}{ Application mode } & \multicolumn{2}{|c|}{$\mathrm{IC}_{50}\left(\mu \mathrm{g} \mathrm{mL} \mathrm{m}^{-1}\right)^{\mathrm{b}}$} \\
\hline & & Leaves & Calyces \\
\hline Control & & $44.98 \mathrm{a}$ & $37.86 \mathrm{a}$ \\
\hline \multirow[t]{3}{*}{ Poultry litter } & Incorporated & $42.30 \mathrm{a}$ & $36.10 \mathrm{a}$ \\
\hline & Coverage & $42.70 \mathrm{a}$ & $37.42 \mathrm{a}$ \\
\hline & Inc. + Cov. & $44.15 \mathrm{a}$ & $37.11 \mathrm{a}$ \\
\hline \multirow[t]{3}{*}{ Organosuper $^{\circledR}$} & Incorporated & $42.43 \mathrm{a}$ & $35.79 \mathrm{a}$ \\
\hline & Coverage & $44.37 \mathrm{a}$ & $37.11 \mathrm{a}$ \\
\hline & Inc. + Cov. & $43.40 \mathrm{a}$ & $38.65 \mathrm{a}$ \\
\hline Means & & 43.48 & 37.15 \\
\hline
\end{tabular}

${ }^{\mathrm{a}}$ The values represent means of triplicate measurements; ${ }^{\mathrm{b}} \mathrm{IC}_{50}=$ concentration for $50 \%$ inhibition of DPPH remaining. The means followed by same letter in column do not differ based on the Tukey test $(\mathrm{p}<0.05)$.

Table 3. $\mathrm{IC}_{50}$ of methanol extract of $H$. sabdariffa leaves and calyces cultivated with poultry litter, organosuper ${ }^{\circledR}$ plus a $^{2}$ control against human cancer cell lines ${ }^{\mathrm{a}}$.

\begin{tabular}{|c|c|c|c|c|c|c|c|}
\hline \multirow{3}{*}{ Cancer cell line } & \multicolumn{7}{|c|}{$\mathrm{IC}_{50}\left(\mu \mathrm{g} \mathrm{mL^{-1 }}\right)_{\mathrm{b}}$} \\
\hline & \multicolumn{3}{|c|}{ Leaves } & \multicolumn{3}{|c|}{ Calyces } & \multirow[b]{2}{*}{ Dox. } \\
\hline & $\begin{array}{c}\text { Poultry } \\
\text { litter }\end{array}$ & Organo $^{c}$ & Control & $\begin{array}{c}\text { Poultry } \\
\text { litter }\end{array}$ & Organo $^{c}$ & Control & \\
\hline Melanoma (UACC-62) & $>100$ & 32.56 & 64.94 & 56.4 & 83.72 & $>100$ & 0.06 \\
\hline $\mathrm{U} 251$ & nd & nd & nd & $>100$ & $>100$ & nd & 0.03 \\
\hline Breast (MCF7) & nd & nd & nd & $>100$ & $>100$ & nd & 0.05 \\
\hline Leukemia (K-562) & 43.20 & nd & 49.9 & 1.16 & 0.12 & 2.24 & 0.06 \\
\hline Ovary (OVCAR) & nd & nd & nd & 95.77 & $>100$ & nd & 0.28 \\
\hline Prostate (PCO-3) & nd & nd & nd & $>100$ & $>100$ & nd & 0.21 \\
\hline Colon (HT29) & nd & nd & nd & $>100$ & $>100$ & nd & 0.18 \\
\hline Kidney (786-0) & nd & nd & nd & $>100$ & $>100$ & nd & 0.07 \\
\hline Vero & nd & nd & nd & $>100$ & $>100$ & nd & 0.66 \\
\hline
\end{tabular}

${ }^{a}$ Values determined by nonlinear regression analysis using GraphPad Prism $\left(\mathrm{r}^{2}>0.9\right)$. nd, not determined; ${ }^{\mathrm{b}} \mathrm{IC}_{50}=$ concentration for $50 \%$ inhibition of cell growth; ${ }^{\mathrm{C}}$ organo $=$ organosuper $^{\circledR}$. 
A

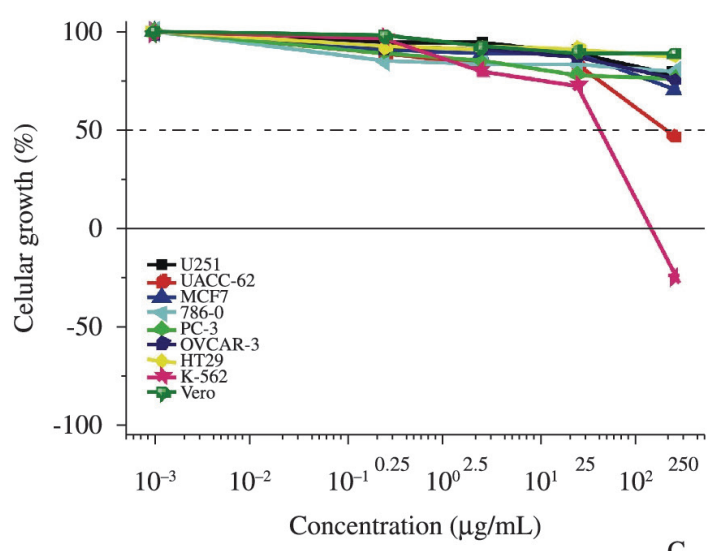

C

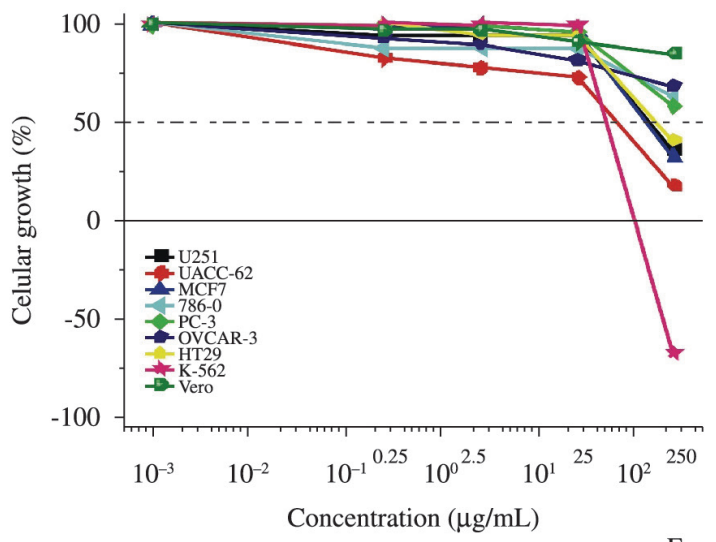

E

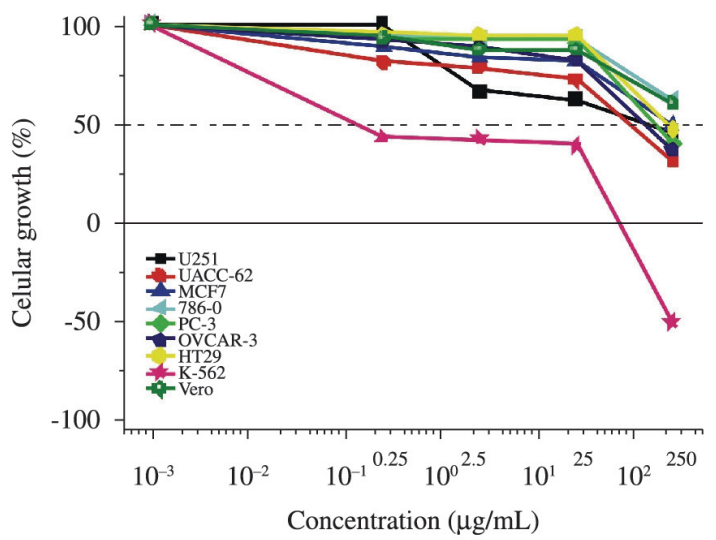

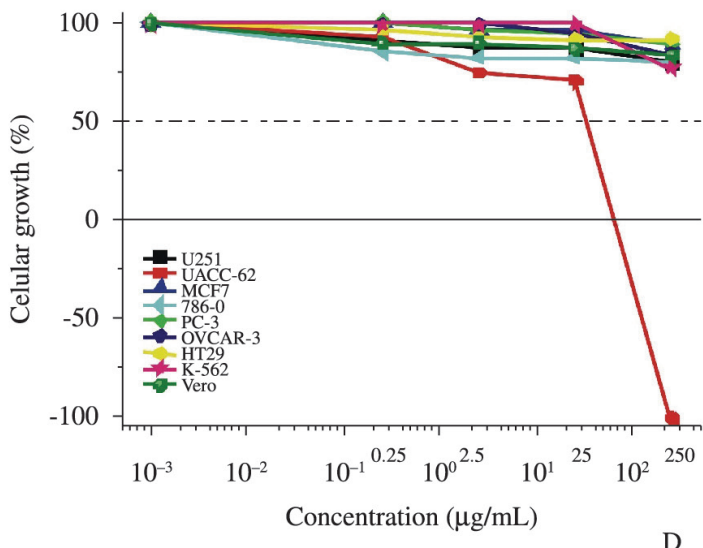
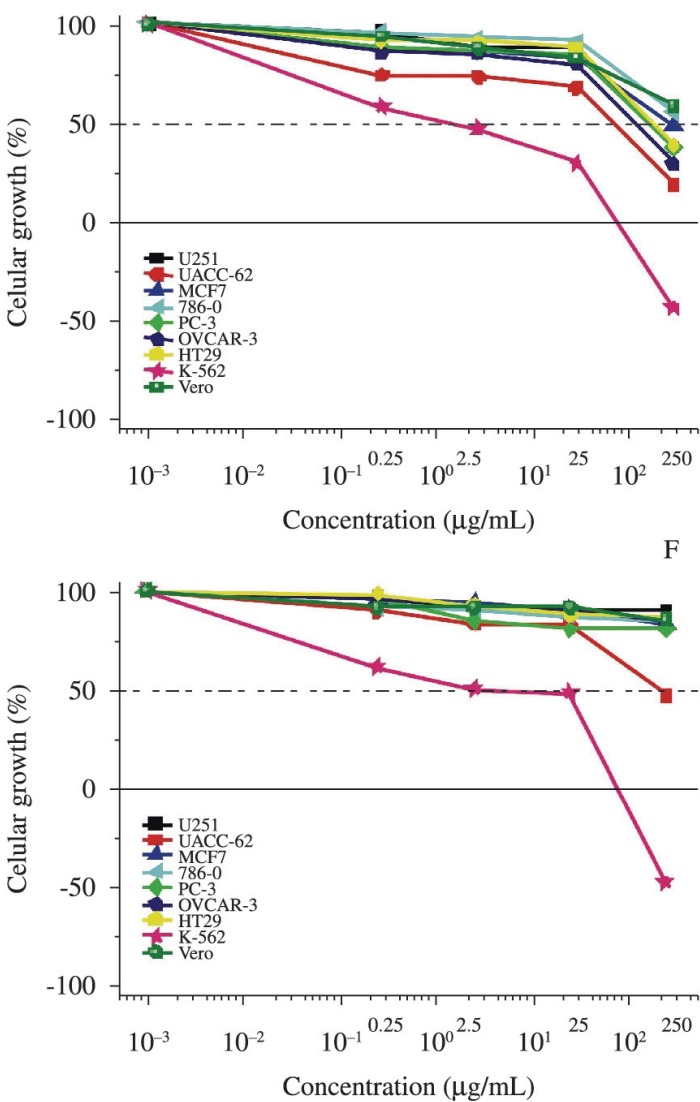

Figure 1. Activity of methanol extract from leaves cultivated with poultry litter incorporated (A), organosuper ${ }^{\circledR}$ incorporated (B) and control (C), and calyces cultivated with poultry litter incorporated (D), organosuper ${ }^{\circledR}$ incorporated (E) and control (F) after $48 \mathrm{~h}$ exposure against human cancer cell lines.

from 0.3 to $2.4 \%$, suggesting that Hibiscus calyces can be a rich source of these compounds compared to other natural plant sources. However, when the methanol extracts of leaves and calyces were evaluated individually, the total phenols and flavonoids were higher with poultry litter and incorporated organosuper ${ }^{\circledR}$.

The content of phenolic compounds and other phytochemicals present in medicinal plants, as well as in fruits and vegetables, is largely influenced by the type of cultivation, genetic factors, environmental conditions, in addition to the degree of maturation and the variety of the plant (Koleva et al., 2002; Melo et al., 2006). The fact that the highest phenol content was obtained using soil with poultry litter and incorporated organosuper ${ }^{\circledR}$ is due to an improvement in soil physical properties, such as an increased soil water retention (Karamanos et al., 2004); 
this is in addition to an improvement in the balance of soil nutrients (Blaise, 2006).

Of the various chemical methods used to determine the antioxidant capacity of a compound in capturing free radicals, DPPH is one of the most used because it is considered to be practical, fast and stable (Espin et al., 2000). This method is based on the ability of compounds to donate a proton to DPPH and form stable resonance structures. The test data against the free radical are presented in Table 2. $\mathrm{IC}_{50}$ values (concentration for $50 \%$ inhibition of DPPH remaining) were calculated via the graph of $\%$ I (inhibition percentage) versus the extract concentration in $\mathrm{mg} \mathrm{mL}^{-1}$. The percentage of DPPH inhibition (\% I) was calculated using the equation $\% \mathrm{I}:\left(\mathrm{A}_{0}-\mathrm{A} / \mathrm{A}_{0}\right) \times 100$, where $\mathrm{A}_{0}$ is the absorbance of DPPH (control) and $\mathrm{A}$ is the absorbance of sample plus DPPH. The amount of extract required to inhibit $50 \%$ of DPPH was not influenced by organic waste or the application mode studied.

The antioxidant effects of extracts were most likely due to a subgroup of flavonoids, anthocyanins, which have been reported in the literature as the main constituents of H. sabdariffa (Strack and Wray, 1986; Mazza and Miniati, 1993; Tsai et al., 2002). These substances display conjugation to form stable resonance structures during the formation of free radicals, highlighting the high response to the test with the free radical DPPH.

Given that natural substances such as phenolic compounds, especially flavonoids (anthocyanins and anthoxanthins) may be responsible for the protective effect against the risk of many disease processes, such as cancer (Wang and Mazza, 2002; Katsube et al., 2003), cardiovascular and circulatory diseases (Stoclet et al., 2004), diabetes and Alzheimer's disease (Hertog et al., 1997; Ishige et al., 2001; Abdille et al., 2005), Given that the methanol extracts of leaves and calyces of $H$. sabdariffa that were cultivated with poultry litter and organosuper ${ }^{\circledR}$ showed higher phenolics and flavonoids content, these extracts were therefore evaluated for in vitro anticancer activity against cultured human cancer lines, including melanoma (UACC-62), breast (MCF7) leukemia (K-562), ovary (OVCAR-3), prostate (PC-3), colon (HT29), kidney (786-0), glaucoma (U251) and Vero cells. The methanol extract from calyces showed significant selective activity against a leukemia line (K-562), with concentrationdependent, cytotoxic and cytocidal effects.

Studies evaluating cell proliferation suggest that the inhibition of HeLa cell proliferation observed for a hot water extract of $H$. sabdariffa flowers may be correlated with the acidic condition induced by the presence of phenolic compounds. These compounds include protocatechuic acid, anthocyanins, quercetin, as well as organic acids, such as citric, malic and tartaric acids (Olvera-Garcia et al., 2008). Studies with human leukemia cells incubated for 24 and $48 \mathrm{~h}$ with protocatechuic acid (3,4-dihidroxibenzóico, PCA) at concentrations of $0.2,0.5,1.0$ and $2.0 \mathrm{mM}$ showed a concentration-dependent inhibitory effect on cell growth (Ali et al., 2005; Falade et al., 2005). This compound induced internucleosomal DNA fragmentation and cellular morphological changes characteristic of apoptosis (Tseng et al., 2000).

All of the extracts of $H$. sabdariffa that were studied as a function of cultivation with organic wastes and application modes exhibited varied phenolic content and antioxidant and anticancer effects. However, the intensity of these effects did not differ significantly with the crop system employed. Furthermore, the anticancer potential was observed in the extract of calyces, independently of the cultivation conditions.

Thus, the results of this study should stimulate further studies of $H$. sabdariffa using other forms of cultivation in an attempt of increase the concentration of potentially active substances, ensuring the effectiveness and subsequent commercialization of the species. Further studies to elucidate the possible compounds involved in anticancer activity will be carried out.

\section{Acknowledgements}

The authors thank CNPq, Fundect and UFGD for financial support. The authors are grateful to Dra. Zefa Valdevina Pereira (Faculdade de Ciências Biológicas e Ambiental - UFGD, Dourados-MS) for botanical identification of the plant.

\section{References}

ABDILLE, MH., SINGH, RP., JAYAPRAKASHA, GK. and JENA, BS., 2005. Antioxidant activity of the extracts from Dillenia indica fruits. Food Chemistry, vol. 90, no. 4, p. 891-896. http:// dx.doi.org/10.1016/j.foodchem.2004.09.002.

ALI, BH., AL WABEL, N. and BLUNDEN, G., 2005. Phytochemical, pharmacological and toxicological aspects of Hibiscus sabdariffa L.: a review. Phytotherapy Research, vol. 19, no. 5, p. 369-375. http://dx.doi.org/10.1002/ptr.1628. PMid:16106391

AMES, BN., SHIGENAGA, MK. and HAGEN, TM., 1993. Oxidants, antioxidants, and the degenerative diseases of aging. Proceedings of the National Academy of Sciences of the United States of America, vol. 90, no. 17, p. 7915-7922. http://dx.doi. org/10.1073/pnas.90.17.7915. PMid:8367443

BLAISE, D., 2006. Yield boll distribution and fiber quality of hybrid cotton (Gossypium hirsutum L.) as influenced by organic and modern methods of cultivation. Journal Agronomy \& Crop Science, vol. 192, no. 4, p. 248-256. http://dx.doi.org/10.1111/ j.1439-037X.2006.00218.x.

BLOIS, MS., 1958. Antioxidant determinations by the use of a stable free radical. Nature, vol. 181, no. 4617, p. 1199-1200. http://dx.doi.org/10.1038/1811199a0.

CHANG, YC., HUANG, HP., HSU, JD., YANG, SF. and WANG, CJ., 2005. Hibiscus anthocyanins rich extract-induced apoptotic cell death in human promyelocytic leukemia cells. Toxicology and Applied Pharmacology, vol. 205, no. 3, p. 201-212. http://dx.doi. org/10.1016/j.taap.2004.10.014. PMid:15922006

CHEN, CC., HSU, JD., WANG, SF., CHIANG, HC., YANG, MY., KAO, ES., HO, YC. and WANG, CJ., 2003. Hibiscus sabdariffa extract inhibits the development of atherosclerosis in cholesterolfed rabbits. Journal of Agricultural and Food Chemistry, vol. 
51, no. 18, p. 5472-5477. http://dx.doi.org/10.1021/jf030065w. PMid:12926900

CHEN, CC., CHOU, FP., HO, YC., LIN, WL., WANG, CP. and HAO, ES., 2004. Inhibitory effects of Hibiscus sabdarriffa L. extract on low-density lipoprotein oxidation and anti-hyperlipidemia in fructose-fed and cholesterol-fed rats. Journal of the Science of Food and Agriculture, vol. 84, no. 15, p. 1989-1996. http:// dx.doi.org/10.1002/jsfa.1872.

ESPÍN, JC., SOLER-RIVAS, C., WICHERS, HJ. and GARCÍAVIGUERA, C., 2000. Anthocyanin-based natural colorants: a new source of antiradical activity for foodstuff. Journal of Agricultural and Food Chemistry, vol. 48, no. 5, p. 1588-1592. http://dx.doi. org/10.1021/jf9911390. PMid:10820063

FALADE, OS., OTEMUYIWA, IO., OLADIPO, A., OYEDAPO, OO., AKINPELU, BA. and ADEWUSI, SR., 2005. The chemical composition and membrane stability activity of some herbs used in local therapy for anemia. Journal of Ethnopharmacology, vol. 102, no. 1, p. 15-22. http://dx.doi.org/10.1016/j.jep.2005.04.034. PMid:16039811

FAROMBI, EO. and FAKOYA, A., 2005. Free radical scavenging and antigenotoxic activities of natural phenolic compounds in dried flowers of Hibiscus sabdariffa L. Molecular Nutrition \& Food Research, vol. 49, no. 12, p. 1120-1128. http://dx.doi. org/10.1002/mnfr.200500084. PMid:16254885

HERTOG, MGL., SWEETNAM, PM., FEHILY, AM., ELWOOD, PC. and KROMHOUT, D., 1997. Antioxidant flavonols and ischemic heart disease in a Welsh population of men: the Caerphilly Study. The American Journal of Clinical Nutrition, vol. 65, no. 5, p. 1489-1494. PMid:9129481.

ISHIGE, K., SCHUBERT, D. and SAGARA, Y., 2001. Flavonoids protect neuronal cells from oxidative stress by three distinct mechanisms. Free Radical Biology \& Medicine, vol. 30, no. 4, p. 433-446. http://dx.doi.org/10.1016/S0891-5849(00)00498-6. PMid:11182299

JULIANI, HR., WELCH, CR., WU, Q., DIOUF, B., MALAINY, D. and SIMON, JE., 2009. Chemistry and quality of Hibiscus (Hibiscus sabdariffa) for developing the natural-product industry in Senegal. Journal of Food Science, vol. 74, no. 2, p. S113-S121. http://dx.doi.org/10.1111/j.1750-3841.2009.01076.x. PMid:19323768

KARAMANOS, AJ., BILALIS, D. and SIDIRAS, N., 2004. Effects of reduced tillage and fertilization practices on soil characteristics, plant water status, growth and yield of upland cotton. Journal Agronomy \& Crop Science, vol. 190, no. 4, p. 262-276. http:// dx.doi.org/10.1111/j.1439-037X.2004.00101.x.

KATSUBE, N., IWASHITA, K., TSUSHIDA, T., YAMAKI, K. and KOBORI, M., 2003. Induction of apoptosis in cancer cells by Bilberry (Vaccinium myrtillus) and the anthocyanins. Journal of Agricultural and Food Chemistry, vol. 51, no. 1, p. 68-75. http:// dx.doi.org/10.1021/jf025781x. PMid:12502387

KOLEVA, II., VAN BEEK, TA., LINSSEN, JPH., GROOT, A. and EVSTATIEVA, LN., 2002. Screening of plant extracts for antioxidant activity: a comparative study on three testing methods. Phytochemical Analysis: PCA, vol. 13, no. 1, p. 8-17. http://dx.doi.org/10.1002/pca.611. PMid:11899609

LEE, MJ., CHOU, FP., TSENG, TH., HSIEH, MH., LIN, MC. and WANG, CJ., 2002. Hibiscus protocatechuic acid or esculetin can inhibit oxidative LDL induced by either copper ion or nitric oxide donor. Journal of Agricultural and Food Chemistry, vol. 50, no. 7, p. 2130-2136. http://dx.doi.org/10.1021/jf011296a. PMid:11902968
LIN, HH., HUANG, HP., HUANG, CC., CHEN, JH. and WANG, CJ., 2005. Hibiscus polyphenol-rich extract induces apoptosis in human gastric carcinoma cells via p53 phosphorylation and p38 MAPK/FasL cascade pathway. Molecular Carcinogenesis, vol. 43, no. 2, p. 86-99. http://dx.doi.org/10.1002/mc.20103. PMid:15791651

LIN, JY. and TANG, CY., 2007. Determination of total phenolic and flavonoid contents in selected fruits and vegetables, as well as their stimulatory effects on mouse splenocyte proliferation. Food Chemistry, vol. 101, no. 1, p. 140-147. http://dx.doi.org/10.1016/j. foodchem.2006.01.014.

MAZZA, G. and MINIATI, E., 1993. Anthocyanins in fruits: vegetables, and grains. Tokyo: Publisher CRC Press London. $144 \mathrm{p}$.

MEDA, A., LAMIEN, CE., ROMITO, M., MILlOGO, J. and NACOULMA, OG., 2005. Determination of the total phenolic, flavonoid and proline contents in burkina fasan honey, as well as their radical scavenging activity. Food Chemistry, vol. 91, no. 3, p. 571-577. http://dx.doi.org/10.1016/j.foodchem.2004.10.006.

MELO, EA., MACIEL, MIS., LIMA, VLAG., LEAL, FLL., CAETANO, ACS. and NASCIMENTO, RJ., 2006. Capacidade antioxidante de hortaliças usualmente consumidas. Ciência e Tecnologia de Alimentos, vol. 26, no. 3, p. 639-644. http://dx.doi. org/10.1590/S0101-20612006000300024.

MORTON, JF., 1987. Roselle Hibiscus sabdariffa L. In Morton, JF. (Ed.). Fruits of warm climates. Miami: Creative Resources Systems. p. 281-286.

MONROY-ORTIZ, C. and CASTILLO-ESPANA, P., 2007. Plantas Medicinales Utilizadas en el Estado de Morelos. 2nd ed. México: Publisher CCNABIO. 405 p.

MULLINS, GL. and BENDFELDT, ES., 2001. Poultry litter as a fertilizer and soil amendment. Blacksburg: Virginia Cooperative Extension. 424 p.

OLVERA-GARCÍA, V., CASTAÑO-TOSTADO, E., REZENDIZLOPEZ, RI., REYNOSO-CAMACHO, R., GONZÁLEZ DE MEJÍA, E., ELIZONDO, G. and LOARCA-PIÑA, G., 2008. Hibiscus sabdariffa L. extracts inhibit the mutagenicity in microsuspension assay and the proliferation of HeLa cells. Journal of Food Science, vol. 73, no. 5, p. T75-T81. http://dx.doi. org/10.1111/j.1750-3841.2008.00781.x. PMid:18577016

RAMAKRISHNA, BV., JAYAPRAKASHA, GK., JENA, BS. and SINGH, RP., 2008. Antioxidant activities of roselle (Hibiscus sabdariffa) calyces and fruit extracts. Journal of Food Science and Technology, vol. 45, no. 3, p. 223-227.

RAMOS, DD., VIEIRA, MC., FORMAGIO, ASN., CARDOSO, CAL., RAMOS, DD. and CARNEVALI, TO., 2011. Atividade antioxidante de Hibiscus sabdariffa L. em função do espaçamento entre plantas e da adubação orgânica. Ciência rural, vol. 41, no. 8, p. 1331-1336. http://dx.doi.org/10.1590/S0103-84782011005000107.

RIBEIRO JÚNIOR, JI. and DE MELO, ALP., 2008. Practical guide for SAEG use. Viçosa: Publisher Leave. 288 p.

SOLER-RIVAS, C., ESPÍN, JC. and WICHERS, HJ., 2000. An easy and fast test to compare total free radical scavenger capacity of foodstuffs. Phytochemical Analysis, vol. 11, p. 330-338. http:// dx.doi.org/10.1002/1099-1565(200009/10)11:5<330::AIDPCA534>3.0.CO;2-G.

SKEHAN, P., STORENG, R., SCUDIERO, D., MONKS, A., MCMAHON, J., VISTICA, D., WARREN, JT., BOKESCH, H., KENNEY, S. and BOYD, MR., 1990. New colorimetric cytotoxicity assay for anticancer-drug screening. Journal of the 
National Cancer Institute, vol. 82, no. 13, p. 1107-1112. http:// dx.doi.org/10.1093/jnci/82.13.1107. PMid:2359136

STOCLET, JC., CHATAIGNEAU, T., NDIAYE, M., OAK, MH., EL BEDOUI, J., CHATAIGNEAU, M. and SCHINI-KERTH, VB., 2004. Vascular protection by dietary polyphenols. European Journal of Pharmacology, vol. 500, no. 1-3, p. 299-313. http:// dx.doi.org/10.1016/j.ejphar.2004.07.034. PMid:15464042

STRACK, D. and WRAY, V., 1986. The Anthocyanins. London: Publisher Chapman \& Hall.

TSENG, TH., KAO, ES., CHU, CY., CHOU, FP., LIN WU, HW. and WANG, CJ., 1997. Protective effects of dried flower extracts of Hibiscus sabdariffa L. against oxidative stress in rat primary hepatocytes. Food and Chemical Toxicology: an international journal published for the British Industrial Biological Research Association, vol. 35, no. 12, p. 1159-1164. http://dx.doi.org/10.1016/ S0278-6915(97)85468-3. PMid:9449221

TSAI, PJ., MCINTOSH, J., PEARCE, P., CAMDEN, B. and JORDAN, BR., 2002. Anthocyanin and antioxidant capacity in roselle (Hibiscus sabdariffa L.) extract. Food Research International, vol. 35, no. 4, p. 351-356. http://dx.doi.org/10.1016/ S0963-9969(01)00129-6.
TSENG, TH., HSU, JD., LO, MH., CHU, CY., CHOU, FP., HUANG, CL. and WANG, CJ., 1998. Inhibitory effect of Hibiscus protocatechuic acid on tumor promotion in mouse skin. Cancer Letters, vol. 126, no. 2, p. 199-207. http://dx.doi.org/10.1016/ S0304-3835(98)00010-X. PMid:9585067

TSENG, TH., KAO, TW., CHU, CY., CHOU, FP., LIN, WL. and WANG, CJ., 2000. Induction of apoptosis by hibiscus protocatechuic acid in human leukemia cells via reduction of retinoblastoma (RB) phosphorylation and $\mathrm{Bcl}-2$ expression. Biochemical Pharmacology, vol. 60, no. 3, p. 307-315. http:// dx.doi.org/10.1016/S0006-2952(00)00322-1. PMid:10856425

WANG, CJ., WANG, JM., LIN, WL., CHU, CY., CHOU, FP. and TSENG, TH., 2000. Protective effect of Hibiscus anthocyanins against tert-butyl hydroperoxide-induced hepatic toxicity in rats. Food and Chemical Toxicology: an international journal published for the British Industrial Biological Research Association, vol. 38, no. 5, p. 411-416. http://dx.doi.org/10.1016/S0278-6915(00)000119. PMid: 10762726

WANG, J. and MAZZA, G., 2002. Effects of anthocyanins and other phenolic compounds on the production of tumor necrosis factor alpha in LPS/IFN-gamma-activated RAW 264.7 macrophages. Journal of Agricultural and Food Chemistry, vol. 50, no. 15, p. 4183-4189. http://dx.doi.org/10.1021/jf011613d. PMid:12105943 